\title{
NEW RECORDS OF THE SOFT SCALE INSECTS HOSTS ASSOCIATED WITH THE PROMISING PARASITOID, SCUTELLISTA CAERULEA (FONSCOLOMBE) (HYMENOPTERA:PTEROMALIDAE) IN EGYPT
}

\author{
SHAABAN ABD-RABOU \\ Plant Protection Research Institute, ARC, Dokki, Giza, Egypt \\ (Manuscript received 17 January 2011)

\begin{abstract}
Scutellista caerulea (Fonscolombe) ( Hymenoptera : Pteromalidae) is one of the most promising parasitoid of soft scale insects of the world and Egypt. The present work dealt with the host range and distribution of this species in Egypt during 20052010. The result indicated that the recorded species was associated with 8 soft scale insect species in 9 governorates, two of them as recorded here as a new host insects for the first time in Egypt. These are Ceroplastes rusci (L.) and Coccus hesperidum L. (Hemipetra : Coccidae). An updating list of parasitoids of soft scale insects in Egypt and a key of these parasitoids were also included.
\end{abstract}

\section{INTRODUCTION}

Scutellista caerulea (Fonscolombe) ) ( Hymenoptera : Pteromalidae) is an egg parasitoid of many scale insects. The adult female oviposits in gravid scales. The parasitoid larva consumes 400-500 scale eggs to complete its development (Saad et al., 1977). The parasitoid, S. caerulea has been used widely in the biological control of olive scales ( El-Minshaway et al., 1978 and Luck (1981). It is the most important enemy attacking S. coffeae in Egypt (El-Minshawy and Saad .1977 and Abd-Raou, 2006). Many Egyptian workers recorded this parasitoid associated with different soft scale species in different locations in Egypt, e.g. Priesner and Hosny (1940), ElMinshawy and Saad (1977), Abu El-Khair (1999), Abd-Rabou (2001 a,b,c, 2004, 2006) and Abd-Rabou and Hafez, (2001) .

The aim of the present work is to study the soft scale insect host range and distribution of $S$. caerulea as well as updating and key of the parasitoids of soft scale insects in Egypt.

\section{MATERIALS AND METHODS}

Samples of soft scale insects were collected from different host plants in Egypt throughout the period of study during 2005 and 2010. Leaves, leaflets, stems and fruits from different hosts were stored in well-ventilated glass tubes for one week for 
monitoring of emergence the adult parasitoid and for identification. Gravid females of soft scale insects (as well as insect species other than these soft scales) were eliminated through stereoscopic examination. Soft scale insects and the parasitoid, $S$. caerulea, available specimens found in Entomological Collection, Plant Protection Research Institute, as well as those available in literature were considered; in the meantime samples collected by the author from different localities were recorded.

\section{RESULTS AND DISCUSSION}

\section{Host Range and distribution of soft scale insects associated with the parasitoid, Scutellista caerulea}

Table (1) showed that the recorded parasitoid, Scutellista caerulea was associated with 8 species of soft scale insects in 9 governorates. Two of them as a new host soft scale insect. These are Ceroplastes floridensis Comstock, Ceroplastes rusci (L.), Coccus hesperidum L. ( new record here), Kilifia acuminata (Signorat), Parasaissetia nigra (Nietner), Saissetia coffee (Walker), Saissetia oleae (Olivier) and Waxiella mimosae (Signoret).

This parasitoid was recorded for the first time in Egypt by Priesner and Hosny, 1940 associated with W. mimosae on Acacia nilotica, Albizzia lebbek, Ficus carica, also $P$. nigra on Ficus sycamorus and S. coffeae on olive in Lower and Upper Egypt . Abu El-Khair (1999) and Abd-Rabou (2001b,c) recorded this parasitoid associated with S. coffeae, S. oleae and C. floridensis. Abou El-Khair (1999) recorded S.caruleae associated with different species of soft scale insects in Alexandria . Also, S.caruleae was recorded attacking C. floridensis infested citrus trees in Beheira governorate (Abd-Rabou,2001C). This parasitoid was reared from $K$. acuminate (AbdRabou and Hafez, 2001). In olive groves infested with $S$. oleae recorded this parasitoid (Abd-Rabou, 2004). Later Abd-Rabou (2006) recorded this parasitoid associated with K.acuminata, C.floridensis, P. nigra, S. coffeae and S. oleae. 
Table 1. Host soft scale insects of the parasitoid, Scutellista caerulea with host plant, distribution and references records

\begin{tabular}{|c|c|c|c|}
\hline Host soft scale Insect & Host Plant & Distrubution & References \\
\hline $\begin{array}{l}\text { Ceroplastes floridensis } \\
\text { Comstock }\end{array}$ & Citrus sp. & $\begin{array}{l}\text { Behira, } \\
\text { Sharqyia }\end{array}$ & $\begin{array}{l}\text { Priesner \& Hosny, } 1940 \text {, } \\
\text { Abd-Rabou,2001c ,2006 } \\
\text { and Present Work }\end{array}$ \\
\hline Ceroplastes rusci (L.), & Citrus sp. & Beni- Suef & Present Work \\
\hline Coccus hesperidum $\mathrm{L}$. & Citrus sp. & Giza & Present Work \\
\hline Kilifia acuminata (Signorat), & Mangefra indica & $\begin{array}{l}\text { Ismailia, } \\
\text { Qayubiya }\end{array}$ & $\begin{array}{l}\text { Abd-Rabou \& Hafez, } \\
\text { 2001, Abd-Rabou, } 2006 \\
\text { and Present Work }\end{array}$ \\
\hline $\begin{array}{l}\text { Parasaissetia nigra } \\
\text { (Nietner), }\end{array}$ & Ficus sycamorus & Upper Egypt & $\begin{array}{l}\text { Priesner and Hosny, } 1940 \\
\text { and Present Work }\end{array}$ \\
\hline Saissetia coffee (Walker), & Olea sp. & $\begin{array}{l}\text { Lower Egypt, } \\
\text { Alexandria }\end{array}$ & $\begin{array}{l}\text { Priesner \& Hosny, 1940, } \\
\text { El-Minshawy \& Saad } \\
\text { (1977), Abd-Rabou, } 2006 \\
\text { and Present Work }\end{array}$ \\
\hline Saissetia oleae (Olivier) & Olea sp. & $\begin{array}{l}\text { Alexandria , } \\
\text { El-Arish }\end{array}$ & $\begin{array}{l}\text { El-Minshawi et al., } 1978 \text {, } \\
\text { Abd-Rabou (2004) and } \\
\text { Present Work }\end{array}$ \\
\hline $\begin{array}{l}\text { Waxiella mimosae } \\
\text { (Signoret) }\end{array}$ & $\begin{array}{l}\text { Acacia nilotica, Albizzia } \\
\text { lebbek, Ficus carica, }\end{array}$ & $\begin{array}{l}\text { Upper Egypt, } \\
\text { Qena }\end{array}$ & $\begin{array}{l}\text { Priesner and Hosny, } 1940 \\
\text { and Present Work }\end{array}$ \\
\hline
\end{tabular}




\section{Key of the parasitoid species attacking soft scale in Egypt:}

\section{Key to Species modified from Abd-Rabou (2001a)}

1. Hind wing basally narrow and stalk-like marginal fringe of wings usually very long; stigmal vein rudirnentary; wings and legs long and slim; body generally non-metallic Alaptus sp.

Hind wing basally narrow and other characters different

2(1). Mesopleuron large, covex, horizontal and without a female groove, middle tarsi with at least the basitarsus with a double row of short, thick, peg-like spines beneath, prepectus not large, notaural lines rarely present, antenna with 1-7 funicle segment. .3 Mesopleuron impressed, often grooved .18

3(2). $\quad$ Fore wing shortened, clearly not reaching apex of gaster ......................6

- $\quad$ Fore wing normal or over nearly reaching apex of gaster .........................4

4(3). Scutellum without such a group of setae, ovipositor and gonostyli hardly protruding caudally Microterys flavus (Howard) Scutellum with a subapical group of dark coarse setae arranged in a more or less compact bundle.

5(4). Mesoscutum with a distinct transverse depression in its posterior onethird, either mesoscutum with a more or less distinct bundle of setae in middle or posterior margin or pronotum has a line of stiff black bristle, sides of propodeum and mesopleura posteriorly more or less dark metallic Diversinervus elegans Silvestri Mesoscutum without a transverse posterior depression, neither mesoscutum with a median bundle of setae nor posterior margin or pronotum with a line of stiff black bristles.

Cheiloneurus sp.

6(3). Scutellum without a distinct tuft or bundle of setae or scale-like setae....7 Scutellum with a group of coarse, long dark setae arranged in a more or less compact tuft or bundle or with two or more scale-like setae marginal vein shorter than stigmal vein, antenna with scape longer than the basal three funicle segments combined

Encyrtus inflelix (Embleton)

7(6). Hypopygium not reaching more than two-third along gaster, scape tending to be subrectangular, the flattened part of upper edge more than one-half as long as the straight part of the lower edge Paraceraptrocerus africanus Giralut

Hypopygium reaching apex of gaster...................................................... 8

8(7). Fore wing with postmarginal vein not longer than stigmal vein...............9 
Fore wing with postmarginal vein longer than stigmal vein, fore wing hyaline, head, dorsum of thorax and mesopleurum with distinctive deep punctate sculpture, scutellum never with apical flange

Blastothrix erythrostethus Walker

9(8). Scape not more than three times as long as broad ............................10

Scape more than three times as long as broad .....................................16

10(9) Mesoscutum or scutellum or both at least partly yellow, orange or pale orange brown

Mesoscutum and scutellum completely dark, not yellow, orange or pale brown, clava strongly obliguely truncate and clearly longer than funicle

Baeoanusia oleae Silvestri

11(10) Maxillary palpi 2-segmented.........................................................12

- Maxillary palpi 3 or 4 segmented, labial palpi 3-segmented.....................13

12(11) Antennal scape 3.6 times as long as the greatest wide

Metaphycus africanus

Antennal scape 2.5 times as long as wide.

Metaphycus helvolus (Compere)

13(11) Maxillary and labial palpi 3-segmented...............................................14

Maxillary palpi 4-segmented and labial palpi 3-segmented .....................15

14(13) Legs with annualr darkish spots on tibiae, antennal scape at least 2.5 times as long as the greatest width Metaphycus lounsburyi (Howard)

Legs without annualr darkish spots on tibiae, antennal scape about 3.5 times as long as the greatest width Metaphycus flavus (Howard)

15(13) Scape more than 2.5 times as long as wide, ovipositor only slightly longer than or subequal in length to middle tibia....

\section{Metaphycus zebratus (Mercet)}

Scape 2.5 times as long as wide, ovipositor shorter than in length to middle tibia Metaphycus anneckei Guerrieri and Noyes

16(9) Fore wing with marginal vein absent, scape more than three times as long as broad Cowperia sp.

Fore wing with marginal vein present. .17

17(16) Ovipositor exserted, pedical subtriangular, shorter than F1, clava not or hardly longer than $\mathrm{F} 1$ Bothriophryne acaciae (Risbec) Ovipositor not exserted, scape more than three times as long as broad. Parechthrodryinus coccidiphagus (Mercet) 
18(2) Tarsi 4-segmented, the gaster distinctly constricted at its junction with propodeum, scutellum with distinct submedian grooves, mesoscutum usually with a median groove. Tetrasticus ceroplastae Girault Tarsi 5-segmented, if rarely some trasi 4-segmented than gaster broadly sessile.

19(18) Gaster subsessile, broadly attached with the propodeum, petiole strongly transverse.

Gaster distinctly constricted at its junction with propodeum, the petiole some times distinct, female antenna with 9, scutellum very long, at least twice as long as mesoscutum, extending well over the gaster.

\section{Scutellista caerulea (Fonscolombe)}

20(19) Antennae at most with 6-segmented, fore wing generally with linea calva, mesopleurn large undivided

Antennae at most with 7-segmented, fore wing generally without linea calva...

21(20) Antennal scape flattened and expanded beneath, not more than twice as long as wide. Marietta picta (Andre) Antennal scape slender, or moderately flattened not less than twice as long as wide. Marietta leopardina Motschulsky

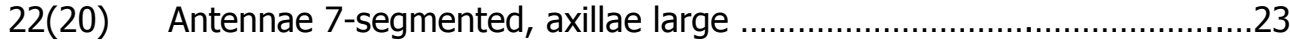

Antennae 8-segmented, axillae small..................................................26

23(20) Scutellum with 3 pairs of setae..........................................................24

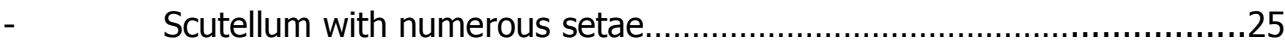

24(23) First funicle segment 3 times as long as pedicel, stigmal vein swollen....

\section{Coccophagus bivittatus Compere}

First funicle segment 1.3 times as long as pedicel, stigmal vein not swollen

Coccophagus lycimnia (Walker)

25(23) Fore coxa yellow, first funicle segment more than twice as long as wide, first club segment longer than wide. Coccophagus scutellaris (Dalman)

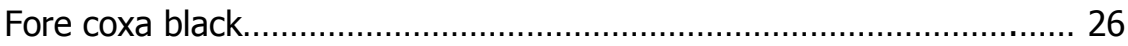

26(22) Scutellum largely yellowish white .... Coccophagus qenai Abd-Rabou Scutellum largely Black Coccophagus ishii Compere

27(22) Submarginal vein 2 setae Encarsia citrina (Craw) Submarginal vein 3 setae Encarsia aurantii (Howard) 


\section{REFERNECES}

1. Abd-Rabou, S. 2001a. Parasitoids attacking soft scales (Homoptera : Coccidea) in Egypt. Egypt. J. Agric. Res. 79 (3): 859-880.

2. Abd-Rabou, S. 2001b. A survey of parasitoids associated with the hemispherical scale, Saissetia coffeae (Walker) (Hemiptera : Coccidae) in North-west Coastal area of Egypt. Bull. Fac. Agric. Cairo, Univ. Special Edition, 1-5.

3. Abd-Rabou, S. 2001c. Parasitoids attacking citrus wax scale, Ceroplastes floridensis Comstock (Homoptera : Coccidae) in Egypt. First Conference of Safe Alternatives of Pesticides for Pest Management, Assiut Univ. 227-233.

4. Abd-Rabou, S. 2004. Augmentative releases of indigenous parasitoids of the Mediterranean Black Scale Saissetia oleae (Oliver) (Hemiptera : Coccidae) on olive in Egypt. Shashpa, 11(1):51-56.

5.Abd-Rabou, S. 2006. Hymenopterous parasitoids as a bioagent for controlling homopterous insects in Egypt. Egypt. Adv. Agric. Res. In Egypt, Vol. (6) 1: 1-65.

6. Abd-Rabou, S. and A. A. Hafez. 2001. Parasitoids attacking the acuminate scale Kilifia acuminata (Signoret) (Hemiptera : Coccidae) in Egypt. J. Egypt. Ger. Soc. Zool., 36 (E) : 39-46.

7. Abou-Elkair, S. 1999. Scale insects (Homoptera : Coccoidea) and their parasitoids on ornamental plants in Alexandria, Egypt. Entomlogica, Bari, 33: 185-195.

8. El-Minshawy, A. M. and A. H. Saad. 1977. Studies on Saissetia coffeae (Walk.) III-Population fluctuation, seasonal mortality, annual increase in population and number increase in population and number of genrations of $S$. coffeae (Walk.). Alex. J. Agric. Res., 24 (3): 527-32.

9. El-Minshawy, A. M., A. H. Saad and S. M. Hammad. 1978. Efficacy of the natural enemy of S. coffeae (Walker), S. oleae and Ceroplastes floridensis Comst (Homoptera:Coccidae). Z. angew. Ent. 85 : 31-37.

10. Luck, R. F. 1981. Parasitic insects introduced as biocontrol for arthropod pests. pp 125-284. In Handbook of pest management agriculture, Vol II (ed) Pimentel. Florida. D. CRC Press, Boca Raton, 501 pp.

11. Priesner, A. and M. Hosny. 1940. Notes on parasites and predators of Coccidae and Aleyrodidae in Egypt. Bull. Soc. Ent. Egypte, 24: 58-70.

12. Saad, A. H., A. M. El-Minshawy and S. M. Hammad. 1977. Studies on the bionomy of S. cyanea Motschulsky (Hym: Pteromalidae). Z. angew. Ent. 83: 155-61. 


\section{تسجيل جديد للحثرات القشرية الرخوة كعائل لطفيل أسكيوتيلستا كاريولى فى مصر}

$$
\text { شعبان عبد ربه }
$$

$$
\text { معرة بحوث وقاية النباتات - مركز البحوث الزراعية - الدقي - جبزة }
$$

طفيل أسكيوتيلستا كاريولى أحد أهم الطفبليات التى تتطفل على الحشرات القشرية الرخوة فى مصر و العالم · تضمن هذا العمل المدى العائلى و التوزيع الجغر افى لهذا الطفيل أثناء الفترة

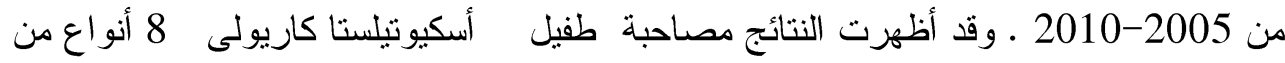
الحشرات القشرية الرخوة التى تنتشر فى 9 محافظات حيث سجل أثنين منهم لأول مرة فى مصر

Coccus hesperidum L. , Ceroplastes rusci (Linnaeus

بالأضافة الى ذلك تم عمل تحديث لقائمة الطفيليات التى تتطفل على الحشرات القشرية الرخوة فى مصر الى جانب عمل مفتاح تصنيفى لهذه الطفيليات. 